\title{
Integrated 1D-2D model for flood simulation in the Vu Gia-Thu Bon delta
}

- Le Song Giang

- Huynh Cong Hoai

- Nguyen Quang Truong

- Nguyen Ngọc Minh

- Tran Thi My Hong

University of Technology, VNU-HCM.

(Manuscript received on 10 th March 2014, accepted on 22 nd December 2014)

\section{ABSTRACT:}

This paper presents an integrated model for calculation of flood in the Vu Gia - Thu Bon river system. In this model, the flow in rivers and channels is considered as onedimensional and described by the Saint Venant equations while the flow on the floodplains is considered as two-dimensional and described by the shallow water equations. All equations are solved by finitevolume method. Roads, railway with conducts on floodplains are also included in the model. The floods in years 1999, 2007, 2009 and 2010 were calculated. The results show that floods in the Vu Gia - Thu Bon delta were simulated in detail with reliable accuracy.

Key Words: Vu Gia - Thu Bon delta, Flood, Integrated 1D-2D model

\section{INTRODUCTION}

Due to the complexity, simulation of flood in a delta is a big challenge to the scientists. In some periods, the water overpasses river bank and overflows floodplains. Nowadays the most advanced and feasible model for simulation of of this flow is integrated 1D-2D. The applications can be found in some publications [7-10]. The advantage of this kind of model is that it can reproduce flood flow in detail, especially on floodplains, with acceptable cost. However NUMERICAL METHOD

\section{Governing equations}

The model was created using F28 hydraulic software [3]. The 1D flow in rivers is solved from the Saint - Venant equations [1]: roads, the infrastructure always exists in the delta and has a noticeable effect on flood flow, weren't modeled accurately or omitted in these models

The aim of this paper to present a new integrated 1D-2D model and its application for the Vu Gia - Thu Bon delta. Floods in the years 1999, 2007, 2009 and 2010 were calculated. The comparison with the field data showed that the model has a quite good accuracy.

$$
\begin{aligned}
& \frac{\partial A}{\partial t}+\frac{\partial Q}{\partial s}=q_{l} \\
& \frac{\partial Q}{\partial}+\frac{\partial}{\partial s}\left(\frac{Q^{2}}{A}\right)+g A \frac{\partial \eta}{\partial s}+g A \frac{|Q| Q}{K^{2}}-u_{l} q_{l}=0
\end{aligned}
$$


The 2D flow on floodplains is solved from the shallow water equations [1]. In conservation form, they are written:

$$
\begin{aligned}
& \frac{\partial \eta}{\partial t}+\nabla \cdot \mathbf{q}=q_{v} \\
& \frac{\partial \mathbf{q}}{\partial t}+\nabla \cdot \mathbf{F}(\mathbf{q})=\mathbf{b}(\mathbf{q})
\end{aligned}
$$

In these equations, $\eta$ - the water level; $\mathrm{Q}, \mathrm{A}$ and $\mathrm{K}$ - the flow rate, the cross section area and the flow rate module for 1D flow; $q_{l}$ and $u_{l}$-the lateral inflow along the river and its axial component of velocity; $\mathbf{q}=\left[q_{x}, q_{y}\right]^{T}=D \mathbf{U}-$ the vector of flow rate per unit width in $2 \mathrm{D}$ flow; $\mathbf{U}=\left[u_{x}, u_{y}\right]^{T}-$ the $2 \mathrm{D}$ depth-averaged velocity vector; $D$ - the water depth; $\nabla$ - the differential operator; $\mathbf{F}(\mathbf{q})$ - the flux vector of flow rate; and $\mathbf{b}(\mathbf{q})$ - the vector of external forces. The flux vector, $\mathbf{F}(\mathbf{q})$, and external forces vector, $\mathbf{b}(\mathbf{q})$, have the forms:

$$
\begin{aligned}
& \mathbf{F}(\mathbf{q})=\left[\begin{array}{l}
q_{x} \mathbf{U}-A_{H} D \partial \mathbf{U} / \partial x \\
q_{y} \mathbf{U}-A_{H} D \partial \mathbf{U} / \partial y
\end{array}\right] \\
& \mathbf{b}(\mathbf{q})=\left[\begin{array}{l}
-g D \partial \eta / \partial x-\left(\tau_{b x}-\tau_{w x}\right) / \rho+f q_{y}+u_{a} q_{v} \\
-g D \partial \eta / \partial y-\left(\tau_{b y}-\tau_{w y}\right) / \rho-f q_{x}+v_{a} q_{v}
\end{array}\right]
\end{aligned}
$$

Where $f$-Coriolis parameter; $\left(\tau_{\mathrm{wx}}, \tau_{\mathrm{wy}}\right)-$ the shear stress on water surface due to the wind; $\left(\tau_{\text {bx }}, \tau_{\text {by }}\right)$ - the bottom shear stress; $A_{H}$ - the eddy viscosity; $q_{v}$ and $u_{a}, v_{a}$ - lateral inflow per unit surface area and its velocity components.

In the model, the bottom shear stress is calculated using Manning's formula:

$\left(\frac{\tau_{b x}}{\rho}, \frac{\tau_{b y}}{\rho}\right)=\frac{g n^{2}}{D^{1 / 3}} \sqrt{u_{x}^{2}+u_{y}^{2}}\left(u_{x}, u_{y}\right)$

And the eddy viscosity is calculated using Elder's formula [2]:

$A_{H}=6 u_{*} D$

Where $n$ - the Manning's roughness coefficient; $u_{*}$ - the bottom shear stress velocity.

On the floodplain, there are many roads and railway. Their existance has a certain effect on flood. In the model, they are considered as broad-crested spillway (Figure 1). The discharge per unit width is calculated using formulas (in neglecting velocity head):

$q=m \sqrt{2 g}\left(\eta_{u p}-z_{c t}\right)^{1,5} \quad$ (free overfall)

Or

$$
\begin{aligned}
q=\varphi_{n}\left(\eta_{u p}-\eta_{\text {down }}\right) \sqrt{2 g\left(\eta_{u p}-z_{c t}\right)} & (\text { submerged flow })
\end{aligned}
$$

Where: $\eta_{u p}$ and $\eta_{\text {down }}$ - the water levels at up- and down-stream of spillway; $z_{c t}$ - the crest elevation; $m$ and $\varphi_{n}$ - the discharge and velocity coefficients.

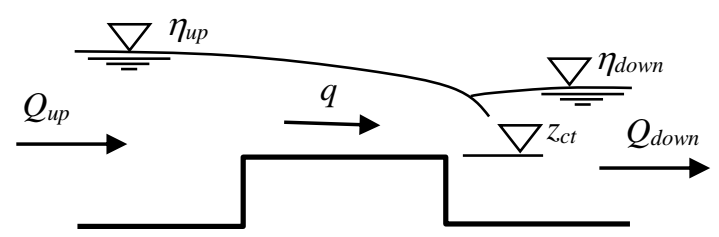

Figure 1. Broad-crested spillway

The flow in the conducts under railway and roads is considered as 1D and described by Saint-Venant equations (1) and (2).

Two types of links between 1D and 2D flows are considered: by the water level at super nodes; and by discharge from 2D nodes to 1D sections at river banks. Super node is the one used by both $1 \mathrm{D}$ and 2D models. The water level at this node is contributed by the inflow from both models. The volume of the node is calculated using mass conservation law:

$\frac{d W_{J}}{d t}=\oint_{L} q_{n} d l$

Where $W_{J}$ - the volume of common node $J$; $L$ - the control contour of the node; and $q_{n}$ - the normal to the control contour component of flow rate per unit width.

The second type of link between 1D and 2D model occurs at river bank when flooded. River banks with or without levees in this situation are considered as a broad-crested spillway (fig. 2).

\section{Trang 44}


Its discharge will be also calculated by formulas

(9a) or (9b) and used for evaluating the term $q_{1}$ of eq. (1) and $q_{y}$ of eq. (3)

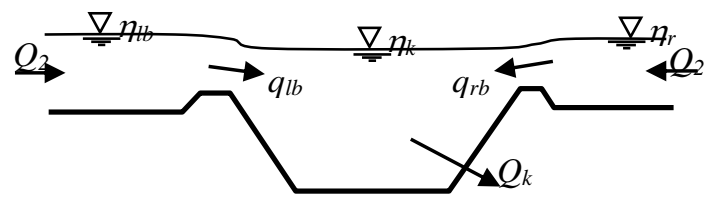

Figure 2. Flooded river banks

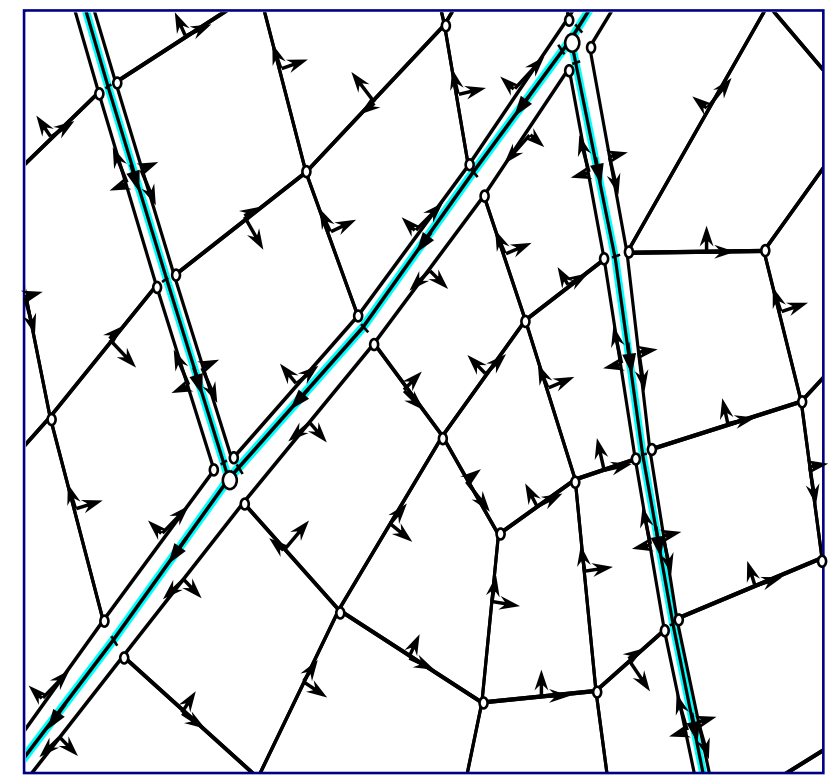

Variables arrangement

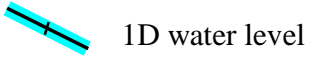

1D discharge

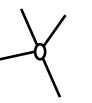

2D water level

$2 \mathrm{D}$ flow-rate
per unit width

Figure 3. The typical fragment of computational mesh 


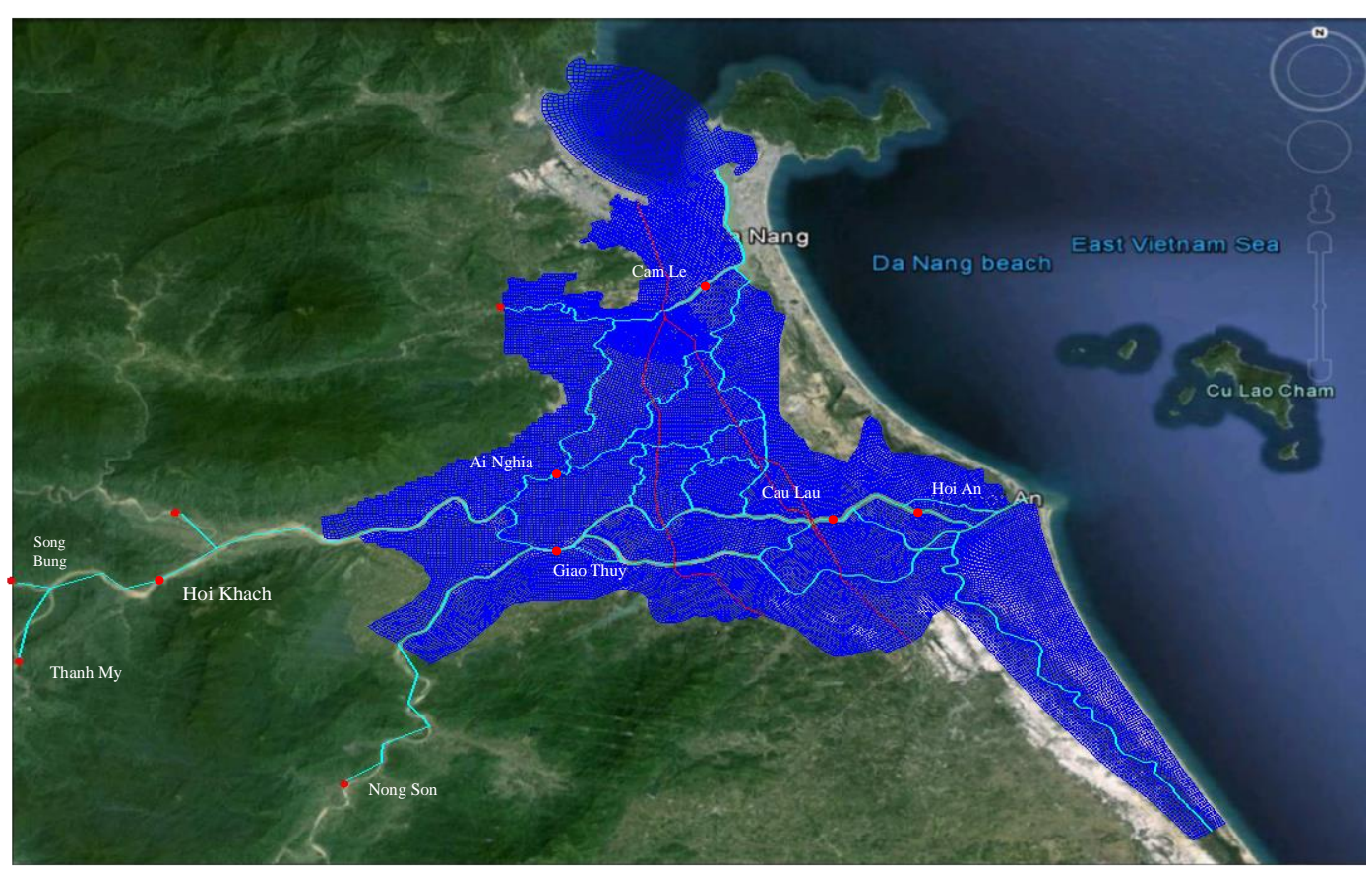

Figure 4. The computational mesh of the Vu Gia-Thu Bon delta

Momentum transfer from one model to other is also considered in this calculation. For the first type of link, all we need is to interpolate the velocity at the interface between 1D and 2D models (at super node). For the second type of link, the momentum exchange is accomplished via the terms $u_{l} q_{l}$ in eq. (2) and $\left(u_{a} q_{v}, v_{a} q_{v}\right)$ in the term $\mathbf{b}(\mathrm{q})$ of eq. (4).

\section{Computational mesh}

For development of the model, two element types are used: 1D for river; and 2D for overland flow. The typical fragment of computational mesh is showed in the Figure 3. The 2D grid is unstructured with quadrilateral

\section{THE MODEL OF VU GIA - THU BON DELTA}

\section{Model set up}

The floods in Vu Gia-Thu Bon rivers in Quang Nam and Da Nang were calculated. Their low basin was covered by a two dimensional mesh comprised of 35632 quadrilateral elements with 38571 nodes. The averaged element area is about $150 \mathrm{~m} \times 150 \mathrm{~m}$. elements. In 1D grid, water level is calculated at the cross sections and while the discharge is calculated at the mid-point of the sections. In $2 \mathrm{D}$ grid, water level is calculated at the nodes and flow-rate per unit width is calculated at mid-point of element's edges.

The $2 \mathrm{D}$ mesh is discontinueed at the roads or railway and spillways will make the flow conection between two sides.

\section{Solution method}

Equations (1), (2) and (3), (4) are solved by finite volume method $[5,6]$ and equations (9a) and (9b) are solved by semi-analytical one [4].

The bathymetry of the 2D model is created based on the 1/25000 topography map established by MidCentral Hydro-Meteoro-logical Station and the 1/5000 topography map established by Da Nang Construction Department.

\section{Trang 46}


Rivers and channels are modeled by 53 branches with 1718 sections and 1770 cross sections (Figure 6). These cross sections were generated from 108 measured cross sections. The averaged length of section is about $180 \mathrm{~m}$.

The model includes also the national road No.1 and the railway with 132 conducts.

The Manning's roughness value is ranging from 0.016 to 0.052 for rivers and channels while ranging from $0.050-0.095$ for $2 \mathrm{D}$ elements.

There are 3 important upper boundaries: Nong Son, Thanh My and Song Bung (see Figure 6). For these nodes, the boundary condition is the inflow discharges measured or calculated from regression formula. The data is collected from the Mid-Central Hydro-Meteorological Station. For the boundary nodes in the sea, the water level is estimated from tidal constants.
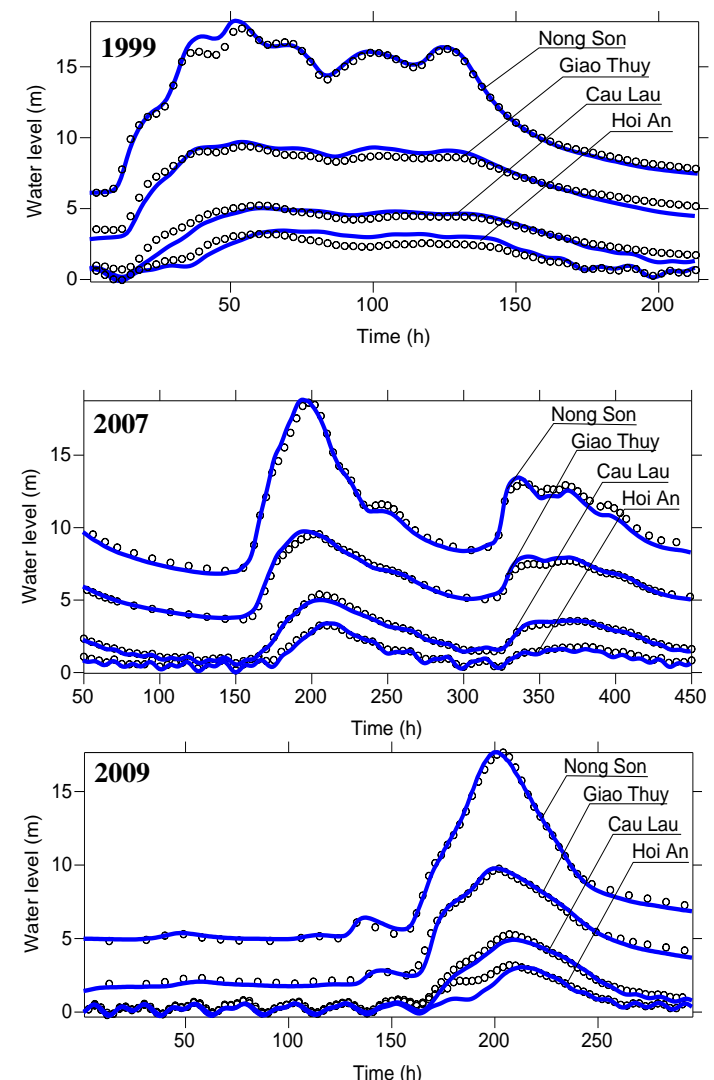

The time step is chosen $2.4 \mathrm{~s}$ to ensure the CFL number less than unity during the calculation. The computational time required for one run (about 9 15 days) is about $6-8$ hours in PC with i7 core of $3.4 \mathrm{GHz}$.

\section{Simulated results and comparisons}

The calculation was conducted for 4 floods in the years 1999, 2007, 2009 and 2010. The simulated water levels at 8 gauging stations in $\mathrm{Vu}$ Gia -Thu Bon delta are shown in Figure 5 (the location of stations is given in Figure 4). These stations are Thanh My, Hoi Khach, Ai Nghia and Cam Le in Vu Gia river; Nong Son, Giao Thuy, Cau Lau and Hoi An in Thu Bon river. The comparison of hydrographs generally shows that the simulated water levels are consistent with observed one.
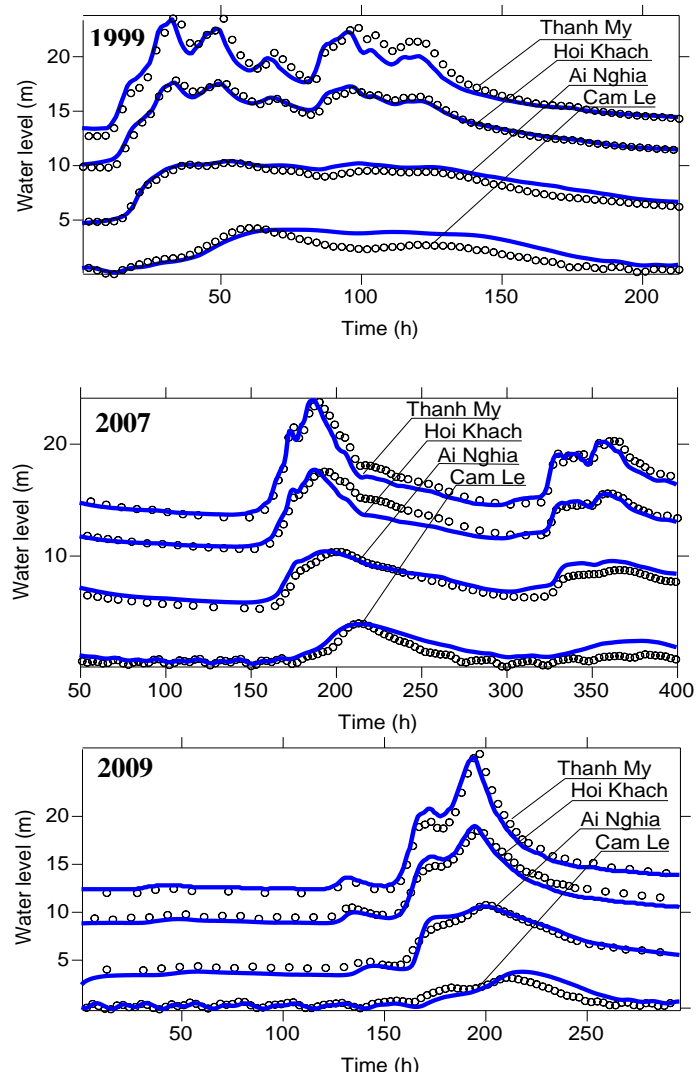

Trang 47 

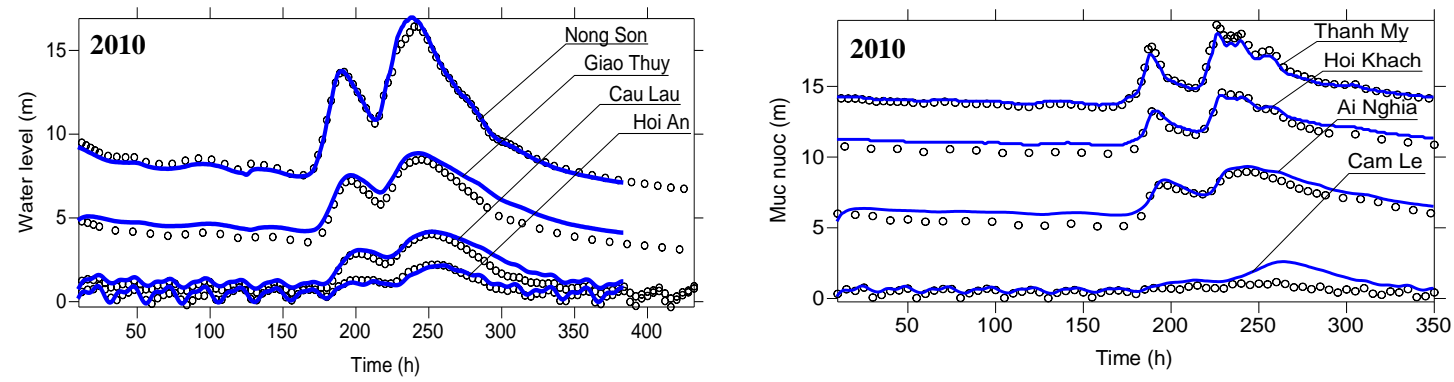

Figure 5. The water levels at 8 gauging stations during 1999, 2007, 2009 and 2010 floods (lines - simulations; symbols - measurements)

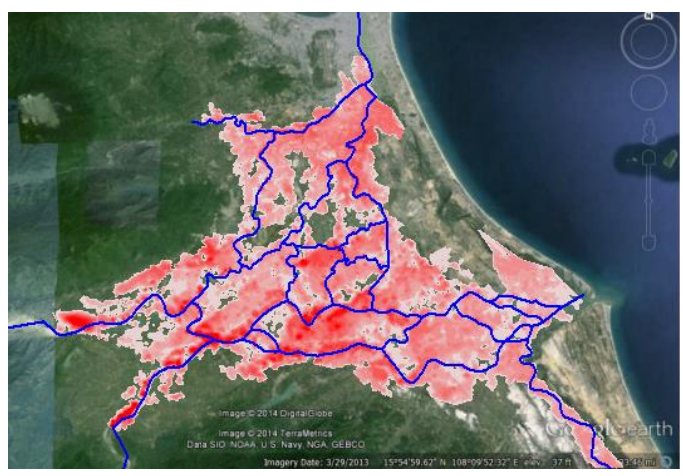

a) Simulated flood map in $30^{\text {th }}$ September, 2009

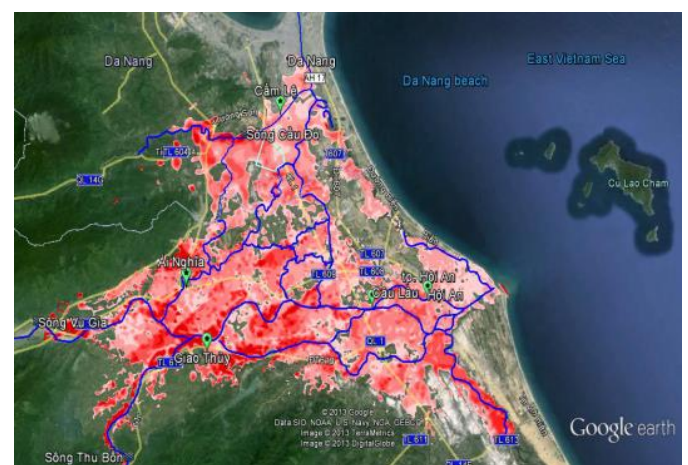

b) Observed flood map in 2009

Figure 6. Flood map in 2009 flood

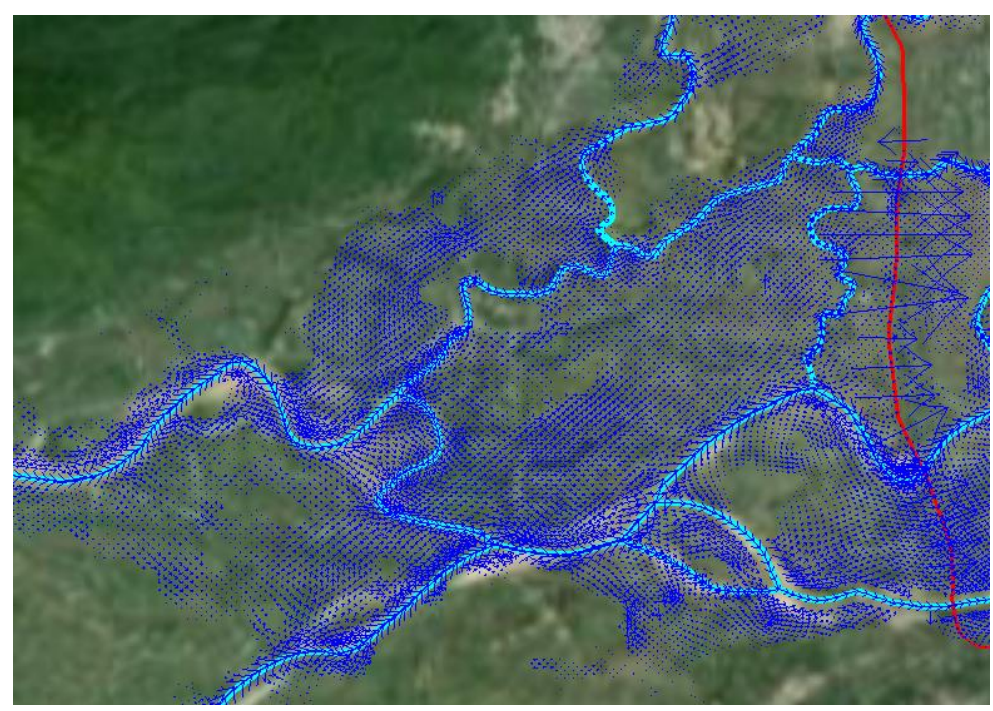

Figure 7. The velocity fields at Quang-Hue in the 1999 flood 
The extent of inundation in the $30^{\text {th }}$ September, 2009 is shown in Figure 6. In this day the water levels at Nong Son and Thanh My are the highest. The comparison with observed flood map in 2009 (by Mid-Central Hydro-Meteological Station) shows that the simulated flood and the observed one are quite close.

\section{CONCLUSIONS}

The paper presented a new integrated 1D2D model for simulation of flood in the Vu Gia - Thu Bon delta. The flow in rivers is assumed 1D while $2 \mathrm{D}$ in floodplains. The roads and railway affecting on flood were also modeled as broad-crested spillways.
The calculations also provided the velocity field during flood time. Figure 7 presents the velocity field at Quang Hue in the flood of the year 1999. We can see that at this location, the water flows on floodplain from $\mathrm{Vu}$ Gia river to Thu Bon one. Such this current created new Quang Hue river as reported in some researches.

The calculation results showed that the model can simulate the flow with a reasonable accuracy. Especially the model can reproduce in detail flow in floodplains and give useful information for further research.

\section{Mô hình tích hợp 1D-2D mô phỏng lũ trên tam giác châu Vu Gia - Thu Bồn}

- Lê Song Giang

- Huỳnh Công Hoài

- Nguyễn Quang Trưởng

- Nguyễn Ngọc Minh

- Trần Thị Mỹ Hồng

Trường Đại học Bách Khoa, ĐHQG-HCM

\section{TÓM TÁ́T:}

Bài báo này trình bày một mô hình cho tính toán dòng chảy lũ trong hệ thống sông Vu Gia _ Thu Bồn. Trong mô hình, dòng chảy trong sông và kênh được xem là một chiều và được giải từ phương trình Saint Venant trong khi dòng chảy trên vùng ngập lũ được xem là hai chiều và được giải từ phương trình nước nông. Các phương trình được giải theo phương pháp thể tích hữu hạn. Đường giao thông, đường sắt cùng với các cống băng qua đường trên vùng ngập lũ cũng được mô hình hóa. Các trận lũ trong các năm 1999, 2007, 2009 và 2010 đã được tính toán. Kết quả tính cho thấy lũ trên tam giác châu Vu Gia - Thu Bồng đã được tính toán mô phỏng một cách chi tiết và với độ chính xác có thể tin cậy.

Từ khóa: Tam giác châu Vu Gia - Thu Bon, lũ, mô hình tích hợp 1D - 2D. 


\section{REFERENCES}

[1] Vreugdenhil, C.B. (1989), Computational Hydraulics, Spring-Verlag, Germany.

[2] Hervouet, J. M. (2003), Hydrodynamique des écoulements à surface libre: modélisation numérique avec la méthode des elements finis, Edition Press de l'Ecole Nationale des Ponts et Chaussées, Paris.

[3] LeSong, G. (2011). Development of an integrated software for calculation of urban flood flow, Report B2007-20$13 \mathrm{~T} Đ$.

[4] LeSong, G. (2009). "Calculation of flow through spillway". Proceeding of the National Congress of Mechanics in the ceremony of thirty year of Institute of Mechanics and Vietnam Journal of Mechanics, Vol. 1, pp. 393 - 401.

[5] LeSong, G., and Tran, T.N.T., (2008), "Numerical calculation of flow in rivers at Can-Gio using two-dimensional numerical model". J. Science and Technology Development, Vol. 11(12), $87-97$.

[6] LeSong, G., and Nguyen, T.P. (2008). "Calculation of the flow in Saigon Dong nai river system using integrated
1D - 2D numerical model". Proceeding of the 2008 National Congress of Fluid Mechanics, pp.141-148.

[7] To Thuy Nga, Le Hung (2012). Impact of flooding discharge from reservoir hydropower in the $\mathrm{Vu}$ Gia - Thu Bon river system to flooding level in the downstream Quang Nam - Da Nang. National Congress on Fluid Mechanics in 2012, pp. 537-572

[8] Lin, B., J.M. Wicks, R.A. Falconer, and K. Adams. "Integrating $1 \mathrm{D}$ and 2D hydrodynamic models for flood simulation." Proceedings of the ICE Water Management, 2005: 19-25

[9] Patro, S., C. Chatterjee, S. Mohanty, R. Singh, and N. S. Raguwanshi. "Flood Inundation Modeling using MIKE FLOOD and Remote Sensing Data." Journal of the Indian Society of Remote Sensing, 2009: 107-118

[10] Dutta, D., Alam, J., Umeda, K., Hayashi, M., and Hironaka, S. (2007). A twodimensional hydrodynamic model for flood inundation simulation: a case study in the lower Mekong river basin, Hydrol. Process., 21, 1223-1237. 